\title{
Detection and quantification of human adenovirus genomes in Acanthamoeba isolated from swimming pools
}

\author{
RODRIGO STAGGEMEIER ${ }^{1}$, THALITA ARANTES ${ }^{2}$, KARIN S. CAUMO ${ }^{3}$, \\ MARILISE B. ROTT ${ }^{3}$ and FERNANDO R. SPILKI ${ }^{1}$
}

\begin{abstract}
${ }^{1}$ Laboratório de Microbiologia Molecular, Universidade Feevale, RS-239, 2755, 96652-000 Novo Hamburgo, RS, Brasil ${ }^{2}$ Laboratório de Virologia, Departamento de Microbiologia, Imunologia e Parasitologia, Instituto de Ciências Básicas da Saúde, Universidade Federal do Rio Grande do Sul/UFRGS, Rua Sarmento Leite, 500, 90050-170 Porto Alegre, RS, Brasil ${ }^{3}$ Laboratório de Parasitologia, Departamento de Microbiologia, Imunologia e Parasitologia, Instituto de Ciências Básicas da Saúde, Universidade Federal do Rio Grande do Sul/UFRGS, Rua Sarmento Leite, 500, 90050-170 Porto Alegre, RS, Brasil
\end{abstract}

Manuscript received on March 2, 2015; accepted for publication on June 6, 2015

\begin{abstract}
Acanthamoeba is the most common free-living environmental amoeba, it may serve as an important vehicle for various microorganisms living in the same environment, such as viruses, being pathogenic to humans. This study aimed to detect and quantify human adenoviruses (HAdV) in Acanthamoebas isolated from water samples collected from swimming pools in the city of Porto Alegre, Southern Brazil. Freeliving amoebae of the genus Acanthamoeba were isolated from water samples, and isolates $(n=16)$ were used to investigate the occurrence of HAdVs. HAdV detection was performed by quantitative real-time polymerase chain reaction (qPCR). HAdVs were detected in $62.5 \%$ (10/16) of Acanthamoeba isolates, ranging from $3.24 \times 10^{3}$ to $5.14 \times 10^{5}$ DNA copies per milliliter of isolate. HAdV viral loads found in this study are not negligible, especially because HAdV infections are associated with several human diseases, including gastroenteritis, respiratory distress, and ocular diseases. These findings reinforce the concept that Acanthamoeba may act as a reservoir and promote HAdV transmission through water.
\end{abstract}

Key words: Acanthamoeba, free-living amoebae, human adenovirus, qPCR, swimming pools.

\section{INTRODUCTION}

Contamination of water sources by viruses, bacteria, and protozoa may cause outbreaks of severe disease, and the burden of gastroenteritis is a major public health problem worldwide (Scheid and Schwarzenberger 2012). Human adenoviruses (HAdVs) have been associated with outbreaks of waterborne diseases, inducing gastroenteritis, respiratory infections, conjunctivitis, meningitis,

Correspondence to: Rodrigo Staggemeier

E-mail: rstaggemeier@gmail.com and encephalitis, among other diseases (KocwaHaluch 2001, Carter 2005). Most HAdV infections are clinically unapparent or associated with mild symptoms. However, serious and sometimes fatal infections may occur, especially among the young, elderly, and immunocompromised (LorenzoMorales et al. 2007). HAdVs belong to the family Adenoviridae, genus Mastadenovirus, which includes more than 60 serotypes, divided into seven species (A to G) (Matsushima et al. 2013). The virus particles are nonenveloped, ranging from 70 
to $100 \mathrm{~nm}$ in diameter. The viral genome is a linear, double-stranded non-segmented DNA (Shenk 1996). HAdVs are excreted in large amounts in human feces and can be found in sewage, raw water, and treated water (Carter 2005).

Acanthamoeba, a free-living protozoan, is ubiquitous in water bodies, being characterized by high resistance to adverse environmental conditions, being able to survive in water even after conventional physical-chemical treatment for human consumption and recreational use, as well as after sewage treatment (Schuster and Visvesvara 2004). Acanthamoeba is the most common free-living environmental amoebae and has a cosmopolitan distribution. It has been isolated from a wide variety of habitats, such as freshwater lakes and rivers (Ettinger et al. 2003, Lorenzo-Morales et al. 2006), swimming pools (Gianinazzi et al. 2009), drinking water systems (Bernander and Kalling 1998), hospital hot water systems (Rohr et al. 1998), groundwater, bottled mineral water, and seawater (Lorenzo-Morales et al. 2005a). Furthermore, it can be found in soil (LorenzoMorales et al. 2005b), contact lens cleaning solutions (Gianinazzi et al. 2009), and surgical material (Foronda 1996). In humans, this protozoan occurs in the gastrointestinal tract, respiratory tract, and central nervous system (Kodet et al. 1998). Amoebae are unicellular phagocytes that feed on microorganisms in their environment, especially inert particles larger than $0.5 \mu \mathrm{m}$ (Raoult and Boyer 2010). Phagocytic amoebae may harbor different bacteria, fungi, and viruses within the same cell. Free-living amoebae can be pathogenic to humans and have been associated with subclinical infections, skin ulcerations, corneal infections, sinusitis, pneumonitis, and meningoencephalitis (Schuster and Visvesvara 2004).
Recreational water is clearly an important source of exposure to Acanthamoeba (LorenzoMorales et al. 2005b). The presence of Acanthamoeba strains in swimming pools has been documented in several studies (Rivera et al. 1993, Tsvetkova et al. 2004, Gianinazzi et al. 2009). In Poland (Górnik and Kuzna-Grygiel 2004) and Finland (Vesaluoma et al. 1995), acanthamoebae were detected in swimming pool water, and in Chile, several genera of amoebae were detected, including Acanthamoeba (Muñoz et al. 2003). In Brazil, Chaves et al. (1985) found acanthamoebae in swimming pools located in the city of Campo Grande, state of Mato Grosso do Sul, CentralWestern Brazil. In the Lagoa dos Patos estuary, Southern Brazil, Sassi et al. (2010) detected the presence of Acanthamoeba in 91.7\% (11/12) of the isolates obtained. Some authors report that these amoebae reach the pools through the water supply, by air or even by swimmers themselves (Muñoz et al. 2003). In the state of Paraná, Southern Brazil, Ruthes et al. (2004) diagnosed conjunctivitis caused by Acanthamoeba in four patients; one of them did not wear contact lenses but used to swim at the club weekly, which the authors suggested might have led to ocular infection with Acanthamoeba.

It is known that amoebae act as predators in the control of microbial communities, serving as an environmental reservoir of pathogens and a vehicle for phylogenetically diverse microorganisms while some of them replicate intracellularly (Barker and Brown 1994, Scheid 2014). Acanthamoebae have demonstrated the ability to serve as hosts for pathogenic bacteria, such as Legionella spp., Mycobacterium avium, Listeria monocytogenes, and Escherichia coli serotype O157, among others (Greub and Raoult 2004). Studies on the relationship between viruses and free-living amoebae emerged in the early 1980s, when Danes and Cerva (1981) demonstrated an association between echoviruses and amoebae. Mattana et al. (2006) reported the capacity of coxsackie B3 viruses to survive within 
amoebae for a 6-month cycle; thus, human viral pathogens may be phagocytized by these protozoa. More recently, a number of giant viruses, such as Mimivirus, Marsseillevirus (Raoult and Boyer 2010), and Pandoravirus (Philippe et al. 2013, Scheid et al. 2008, 2014), have been discovered in acanthamoebae. Such findings suggest that these amoebae have the ability to serve both as a reservoir of and as a replication niche for selected viruses (Raoult and Boyer 2010). Some studies have reported on patients coinfected with human pathogenic viruses and amoebae, including HAdV and Acanthamoeba (Gajdatsy et al. 2000). The first description of the relationship between HAdV and amoebae in nature was published by LorenzoMorales et al. (2007), in which HAdV were detected in $14.4 \%(34 / 236)$ of environmental isolates from amoebae, suggesting that amoebae may play a role as a reservoir of HAdVs. However, this study was conducted with conventional polymerase chain reaction (PCR), and no viral genome quantification was performed. The aim of the current study was to detect and quantify HAdVs in Acanthamoeba isolated from water samples collected from swimming pools in Southern Brazil.

\section{MATERIALS AND METHODS}

\section{Acanthamoeba ISOLATES}

Environmental Acanthamoeba isolates ( $\mathrm{n}=16)$ were collected from swimming pools located in the city of Porto Alegre, Southern Brazil. Acanthamoeba isolation was performed according to Caumo et al. (2009).

\section{VIRAL NUCLEIC ACID EXTRACTION}

Viral nucleic acids (DNA, HAdV) were extracted using the RTP $^{\circledR}$ DNA/RNA Virus Mini Kit (Invitek $^{\mathrm{TM}}$, Berlin, Germany), according to the manufacturer's instructions. An initial volume of $400 \mu \mathrm{L}$ of each concentrated water sample was used for extraction through a silica filter.
The resulting viral DNA was stored at $-80^{\circ} \mathrm{C}$ until processing.

QUANTITATIVE REAL-TIME POLYMERASE CHAIN

REACTION (qPCR)

HAdV molecular detection was performed by qPCR using the commercial kit Platinum ${ }^{\circledR}$ SYBR ${ }^{\circledR}$ Green qPCR SuperMix-UDG (Life Technologies ${ }^{\mathrm{TM}}$ Corporation, Carlsbad, California, USA), according to the manufacturer's instructions. The qPCR reactions were optimized and carried out under the same conditions, and then used as controls for absolute quantification of viral DNA from prototype samples of $\mathrm{HAdV}-5$. The qPCR was carried out in a thermal cycler equipped with the iQ5 ${ }^{\mathrm{TM}}$ Real-Time PCR Detection System (Bio$\operatorname{Rad}^{\mathrm{TM}}$ Laboratories, Hercules, California, USA). The following primers were used: VTB2-HAdVCf (5'-GAGACGTACTTCAGCCTGAAT-3') and VTB2HAdVCr (5'-GATGAACCGCAGCGTCAA-3') (Wolf et al. 2010). In a $25 \mu \mathrm{L}$ reaction volume, we used $12.5 \mu \mathrm{L}$ of the mixture, $1 \mu \mathrm{L}$ of each primer (20 $\mathrm{pM}), 5.5 \mu \mathrm{L}$ of DNAse-/RNAse-free sterile water, and $5.0 \mu \mathrm{L}$ of the nucleic acid extracted from each sample. All reactions included a denaturation cycle at $95^{\circ} \mathrm{C}$ for $10 \mathrm{~min}$, followed by 40 cycles at $95^{\circ} \mathrm{C}$ for $20 \mathrm{~s}$ and combined annealing/extension at $55^{\circ} \mathrm{C}$ for $1 \mathrm{~min}$. Fluorescence data were collected during the annealing/extension step. Then, a denaturation curve was obtained to confirm the specificity of amplification products (a melting step between 55 and $95^{\circ} \mathrm{C}$ ). To generate standard curves, 10 -fold serial dilutions of standard controls from $10^{-1}$ to $10^{-5}$ were prepared, starting at $6.01 \times 10^{7}$ genome copies (gc) per reaction (HAdV-5). All standard controls and samples were run in duplicate. A no template control (NTC) and a negative control were used in each run to confirm that there was no contamination in the assay PCR product specificity was confirmed by high-resolution melting (HRM) analysis and electrophoresis. 


\section{RESULTS}

HAdVs genomes were detected in 62.5\% (10/16) of Acanthamoeba isolates, ranging from $3.24 \times 10^{3}$ to $5.14 \times 10^{5}$ DNA copies per milliliter of isolate. The results are summarized in Table I.

TABLE I

Detection of HAdV in Isolates of Acanthamoeba (Genomecopies/mL).

\begin{tabular}{lc}
\hline Identification & Genome Copies $/ \mathbf{m L}$ \\
\hline Amoeba 81 & $4,89 \mathrm{E}+04$ \\
Amoeba PI4 & $1,28 \mathrm{E}+04$ \\
Amoeba PI8 & $\mathrm{Neg}$ \\
Amoeba PI3 & $2,13 \mathrm{E}+04$ \\
Amoeba PA1 & $\mathrm{Neg}$ \\
Amoeba 84 & $2,09 \mathrm{E}+05$ \\
Amoeba P7 & $6,70 \mathrm{E}+04$ \\
Amoeba PT5 & $\mathrm{Neg}$ \\
Amoeba 95 & $2,46 \mathrm{E}+05$ \\
Amoeba PI2 & $\mathrm{Neg}$ \\
Amoeba P05 & $3,24 \mathrm{E}+03$ \\
Amoeba 121 & $2,23 \mathrm{E}+05$ \\
Amoeba P7 & $\mathrm{Neg}$ \\
Amoeba 123 & $8,53 \mathrm{E}+04$ \\
Amoeba PM6 & $\mathrm{Neg}$ \\
Amoeba 78 & $5,14 \mathrm{E}+05$ \\
\hline Neg: Negative &
\end{tabular}

\section{DISCUSSION}

HAdV and Acanthamoeba can be found in aquatic environments side by side (Lorenzo-Morales et al. 2007), and according to recent reports it seems very likely that both microorganisms may interact (Scheid and Schwarzenberger 2012). Because of the wide distribution and high resistance of HAdVs in aquatic environments, they have been recognized as potential indicators of human fecal contamination. Understanding their interaction with free-living microorganisms is, therefore, of great interest, especially because there are few studies on the interaction between viruses and protozoain the literature (Battistini et al. 2013, Scheid and Schwarzenberger 2012). Free-living amoebae have been reported to host a number of different viruses, such as giant viruses (Suhre 2005, La Scola et al. 2003), adenoviruses (Lorenzo-Morales et al. 2007), rotaviruses (Sepp et al. 1992, Benyahya et al. 1997), and coxsackieviruses (Mattana et al. 2006). In the present study, HAdVs were detected in $62.5 \%$ of Acanthamoeba isolates recovered from environmental samples $(62.5 \%)$, a detection rate higher than that previously reported in Spain (14.4\% of isolates). This may be an effect of the detection technique used in the present study, since qPCR is usually more sensitive than conventional PCR (Donaldson et al. 2002).

In this study, HAdV viral loads in acanthamoebae ranged from $10^{4}$ to $10^{5} \mathrm{gc} / \mathrm{mL}$ in $90 \%$ $(9 / 10)$ of positive samples, while a single isolate had $3.24 \times 10^{3} \mathrm{gc} / \mathrm{mL}$. To the best of our knowledge, no previous study has quantified HAdVs genomes in protozoa, thereby hindering a proper comparison. Quantification of HAdV in this study was expressed as the number of genome copies/ $\mathrm{mL}$ of Acanthamoeba isolate (approximately $10^{6}-10^{7}$ trophozoites per $\mathrm{mL}$ ). Studies around the world show variations in the measurement of HAdVs in water, and this amount may be influenced by the presence of amoebae in water. In river water, HAdV concentrations of $10^{2}-10^{4} \mathrm{gc} / \mathrm{L}$ (Choi and Jiang 2005), $10^{1}-10^{4} \mathrm{gc} / \mathrm{L}$ (Albinana-Gimenez et al. 2009), and $10^{3}-10^{5} \mathrm{gc} / \mathrm{L}$ (Haramoto et al. 2010) have been detected, reaching mean values as low as $<1 \mathrm{gc} / \mathrm{L}$ (van Heerden et al. 2005), $5 \times 10^{2} \mathrm{gc} / \mathrm{L}$ (Wyn-Jones et al. 2011), and $10^{1}-10^{2} \mathrm{gc} / \mathrm{L}$ (Hundesa et al. 2006).

According to Scheid and Schwarzenberger (2012), free-living amoebae appear to be able to act as carriers or vectors of adenoviruses, since the internalized viruses are protected to a high degree against the adverse actions of various disinfection treatments by their host amoebae, thereby playing a certain role in the dispersal of adenoviruses. Nevertheless, those authors concluded that, although there was no proliferation of adenoviruses in 
Acanthamoeba, the virus was able to maintain its infectivity. Their study was the first to prove the ability of free-living amoebae to phagocytize and ingest adenoviruses, and the use of fluorescence microscopy allowed the detection of such viruses within the cytoplasm of the Acanthamoeba trophozoites. Lorenzo-Morales et al. (2007) considered Acanthamoeba a potential reservoir of HAdVs in the aquatic environment, and Battistini et al. (2013) demonstrated the resistance of HAdV for 105 days internalized in amoebae. These protozoa may also serve as a replication niche or training fields for resistance to the microbicidal effects of phagocytic cells, including human macrophages, which represent the first line of defense against invading pathogens (Thomas and Greub 2010, Colson et al. 2013, Scheid 2014). Phagocytosis and macropinocytosis are the main internalization processes in amoebae, being similar to the mechanisms involved in mammalian cells (Ghigo 2010), and free-living amoebae can be simultaneously infected with viruses and other microorganisms, such as bacteria (Yutin and Koonin 2009). More importantly, amoebae play a significant role as a melting pot for genetic exchanges between viruses and bacteria hosted by amoebae, and, as a result, viruses and intracellular bacteria living in amoebae have a sympatric lifestyle and large chimeric genome repertoires (Raoult and Boyer 2010, Thomas and Greub 2010). The HAdVs found in the present study are more likely being internalized and maintained inside amoeba cells, since all the experiments were performed on Acanthamoeba monolayers at the third passage.

Assuming that amoebae are able to carry these pathogens and protect them from external agents, in addition to their association with the diseases mentioned above, the possibility of ocular Acanthamoeba and HAdV coinfection should be considered in non-bacterial and non-fungal cases (Gajdatsy et al. 2000, Lorenzo-Morales et al. 2007). This association should also be considered in cases of pneumonia given the growing body of evidence showing that mimiviruses might cause pneumonia in humans and because respiratory HAdV can reach the respiratory system using the same vectors as those reported by giant viruses (Colson et al. 2013), being able to stand up to the microbicidal effects of human macrophages as they have the ability to resist phagocytic cells (Thomas and Greub 2010). The present findings reinforce the idea that Acanthamoeba may act as a reservoir and promote HAdV transmission through contaminated water.

\section{RESUMO}

Acanthamoeba é a mais comum ameba de vida livre no ambiente, pode atuar como um importante veículo para vários micro-organismos que vivem no mesmo ambiente, tais como vírus, e pode ser patogênica para humanos. Este estudo objetivou detectar e quantificar adenovírus humano (HAdV) em Acanthamoebas isoladas de amostras de águas coletadas de piscinas na cidade de Porto Alegre, no sul do Brasil. Amebas de vida livre do gênero Acanthamoeba foram isolados de amostras de água, e os isolados $(\mathrm{n}=16)$ foram usados para investigar a ocorrência de HAdVs. Detecção de HAdV foi realizada usando reação em cadeia de polimerase quantitativa (qPCR) em tempo real. HAdVs foram detectados em 62.5\% (10/16) dos isolados de Acanthamoeba, variando de $3.24 \times 10^{3}$ a $5.14 \times 10^{5}$ cópias de DNA por mililitro de isolado. As cargas virais de HAdV encontradas nesse estudo não são negligenciáveis, especialmente porque infecções por HAdV são associadas com diferentes doenças humanas, incluindo gastrenterites, doenças respiratórias e oculares. Este estudo reforça o conceito que Acanthamoeba poderia atuar com um reservatório e promover a transmissão de HAdV através da água.

Palavras-chave: Acanthamoeba, ameba de vida livre, adenovírus humano, qPCR, piscinas.

\section{REFERENCES}

Albinana-Gimenez N, Miasgotovich MP, CALGUa B, Huguet JM, MATiA L AND GiRONES R. 2009. Analysis of Adenoviruses and Polyomaviruses quantified by PCR as indicators of water quality in source and drinking-water treatment plants. Water Res 43: 2011-2019. 
BARKER J AND BROWN MR. 1994. Trojan horses of the microbial world: protozoa and the survival of bacterial pathogens in the environment. Microbiol 140: 1253-1259.

BATTISTINI R, MARCUCCI E, VERANIA M, Di GIUSEPPE G, DINI F AND CARDUCCIA A. 2013. Ciliate-adenovirus interactions in experimental co-cultures of Euplotes octocarinatus and in wastewater environment. Eur J Protistol 49: 381-388.

BENYAHYA M, LAVERAN H, BoHATIER J, SENAUd J AND ETTAYEBI M. 1997. Interactions between the ciliated protozoan Tetrahymena pyriformis and the simian rotavirus SA11. Eur J Protistol 33: 211-213.

BERNANDER S AND KALLINGS I. 1998. Human parasites and amoeba: lower warm-water temperature is favourable to Legionella bacteria. Lakartidningen 95: 4340-4344.

CARTER MJ. 2005. Enterically infecting viruses: pathogenicity, transmission and significance for food and waterborne infection. J Appl Microbiol 98: 1354-1380.

CAUMO K, FRASSON AP, PENS CJ, PANATIERI LF, FRAZZON AP AND ROTT MB. 2009. Potentially pathogenic Acanthamoeba in swimming pools: a survey in the southern Brazilian city of Porto Alegre. Ann Trop Med Parasitol 103: 477-485.

Chaves CM, Rocha AA, Melhem MSC, SAntos R, FORONDA AS, BARROS LSP AND BARAZA AMC. 1985. Condições Sanitárias de Águas de Piscinas de Campo Grande, Mato Grosso do Sul. Rev DAE 45: 88-94.

CHOI S AND JIANG SC. 2005. Real-time PCR quantification of human adenoviruses in urban rivers indicates genome prevalence but low infectivity. Appl Environ Microbiol 71: 7426-7533.

COLSON P, LA SCOLA B AND RAOUlT D. 2013. Giant Viruses of Amoebae as Potential Human Pathogens. Intervirol 56: 376-385.

DANES L AND CERVA L. 1981. Survival of polioviruses and echoviruses in Acanthamoeba castellanii cultivated in vitro. J Hyg Epid Microb Im 25: 169-174.

DONALDSON KA, GRIFFIN DW AND PAUL JH. 2002. Detection, quantitation and identification of enteroviruses from surface waters and sponge tissue from the Florida Keys using real-time RT-PCR. Water Res 36: 2505-2514.

ETTINGER MR, WEBB SR, HARRIS SA, MCININCH SP, C GARMAN G AND BROWN BL. 2003. Distribution of freeliving amoebae in James River, Virginia, USA. Parasitol Res 89: 6-15.

FORONDA AS. 1996. Tratado de Infectologia. Atheneu, São Paulo, $2^{\mathrm{a}}$ v., p. 1160-1166.

GAJDATSY AD, KOSMIN A AND BARRETT GD. 2000. Coexistent adenoviral keratokonjunctivitis and Acanthamoeba keratitis. Clin Exp Ophthalmol 28: 434-436.

GHIGO E. 2010. A Dilemma for Viruses and Giant Viruses: Which Endocytic Pathway to Use to Enter Cells? Intervirol 53: 274-283.
GiANINAZZI C, SCHILD M, WÜTHRICH F, MÜLlER N, SCHÜRCH N AND GOTTSTEIN B. 2009. Potentially human pathogenic Acanthamoeba isolated from a heated indoor swimming pool in Switzerland. Exp Parasitol 121: 180186.

GÓRNIK K AND KUŹNA-GRYGIEL W. 2004. Presence of virulent strains of amphizoic amoebae in swimming pools of the city of Szczecin. Ann Agric Environ Med 11: 233 236.

GREUB G AND RAOULT D. 2004. Microorganisms resistant to free-living amoebae. Clin Microbiol Rev 17: 413-433.

HARAMOTO E, KITAJIMA M, KATAYAMA H AND OHGAKI S. 2010. Real-time PCR detection of adenoviruses, polyomaviruses, and torque teno viruses in river water in Japan. Water Res 44: 1747-1752.

Hundesa A, Maluquer de Motes C, Bofill-Mas S, ALBINAMA-GIMENEZ N AND GIRONES R. 2006. Identification of Human and Animal Adenoviruses and Polyomaviruses for Determination of Sources of Fecal Contamination in the Environment. Appl Environ Microbiol 72: 7886-7893.

KoCWA-HALUCH R. 2001. Waterborne enteroviruses as a hazard for human health. Polish J Environ Stud 10: 485487.

KODET R, NOHÝNKOVÁ E, TICHÝ M, SOUKUP J AND VISVESVARA GS. 1998. Amebic encephalitis caused by Balamuthia mandrillaris in a Czech child: description of the first case from Europe. Pathol Res Pract 194: 423-429.

La Scola B, Audic S, Robert C, Jungang L, DE LAMBALlERIE X, DRANCOURT M, BIRTLES R, ClAVERIE JM AND RAOULT D. 2003. A giant virus in amoebae. Science 299: 2033.

LORENZO-MORALES J, CORONADO-ALVAREZ N, MARTINEZCARRETERo E, MACIVER S AND VALlADARES B. 2007. Detection of four adenovirus serotypes within waterisolated strains of Acanthamoeba in the Canary Islands, Spain. Am J Trop Med Hyg 77: 753-756.

LORENZO-MORALES J, LINDO JF, MARTINEZ E, CALDER D, FIGUERUELO E, VALLADARES B AND ORTEGA-RIVAS A. 2005a. Pathogenic Acanthamoeba strains from water sources in Jamaica, West Indies. Ann Trop Med Parasitol 99: 751-758.

Lorenzo-Morales J, MONTEVERdE-MirandA CA, JiMÉNEZ C, TEJEDOR ML, VALLADARES B AND ORTEGA-RIVAS A. 2005b. Evaluation of Acanthamoeba isolates from environmental sources in Tenerife, Canary Islands, Spain. Ann Agric Environ Med 12: 233-236.

LORENZO-MORALES J, ORTEGA-RIVAS A, MARTÍNEZ E, KhoubBane M, ARTigas P, PERIAGO MV, Foronda P, ABREU-ACOSTA N, VALLADARES B AND MAS-COMA S. 2006. Acanthamoeba isolates belonging to T1, T2, T3, T4 and $\mathrm{T} 7$ genotypes from environmental freshwater samples in the Nile Delta region, Egypt. Actatropica 100: 63-69. 
MATSUSHIMA Y ET AL. 2013. Genome sequence of a novel virus of the species human adenovirus D associated with acute gastroenteritis. Genome Announc 1: 1-2.

Mattana A, Serra C, Mariotti E, Delogu G, Fiori P AND CAPPUCCINELLI P. 2006. Acanthamoeba castellanii promotion of in vitro survival and transmission of Coxsackie B3 viruses. Eukaryot Cell 5: 665-671.

MuÑOZ V, REYES H, TOCHE P, CÁRCAMO C AND GOTTLIEB B. 2003. Aislamiento de amebas de vida libre en piscinas públicas de Santiago de Chile. Parasitol Latinoam 58: 106111.

PHILIPPE N ET AL. 2013. Pandoraviruses: amoeba viruses with genomes up to $2.5 \mathrm{Mb}$. Science 341: 281-286.

RAOUlt D AND BOYER M. 2010. Amoebae as Genitors and Reservoirs of Giant Viruses. Intervirol 53: 321-329.

RIVERA F, RAMÍREZ E, BONILLA P, CALDERÓNA, GALLEGOS E, RODRÍGUEZ S, ORTIZ R, ZALDÍVAR B, RAMÍREZ P AND DURÁN A. 1993. Pathogenic and free-living amoebae isolated from swimming pools and physiotherapy tubs in Mexico. Environ Res 62: 43-52.

RoHr U, Weber S, Michel R, SELENKA F AND WILHELM M. 1998. Comparison of free-living amoebae in hot water systems of hospitals with isolates from moist sanitary areas by identifying genera and determining temperature tolerance. Appl Environ Microbiol 64: 1822-1824.

RUTHES ACC, WAHAB S, WAHAB N, MOREIRA H AND MOREIRA L. 2004. Conjunctivitis presumably due to Acanthamoeba. Arq Bras Oftalmol 67: 897-900.

SASSI RAM ET AL. 2010. Pathogenic Microorganisms in Seawater Samples at the Port in Rio Grande, RS, Brazil: A Public Health Issue. Vittalle 22: 51-61.

SCHEID P. 2014. Relevance of free-living amoebae as hosts for phylogenetically diverse microorganisms. Parasitol Res 113: 2407-2414.

SCHEID P, BALCZUN C AND SCHAUB G. 2014. Some secrets are revealed: parasitic keratitis amoebae as vectors of the scarcely described pandoraviruses to humans. Parasitol Res 113: 3759-3764.

SCHEID P, PRESSMAR S, RICHARD G, ZÖLlER L AND MICHEL R. 2008. An extraordinary endocytobiont in Acanthamoeba sp. isolated from a patient with keratitis. Parasitol Res 102: 945-950.
SCHEID P AND SCHWARZENBERGER R. 2012. Acanthamoeba spp. as vehicle and reservoir of adenoviruses. Parasitol Res 111: 479-485.

SCHUSTER FL AND VISVESVARA GS. 2004. Opportunistic amoebae: challenges in prophylaxis and treatment. Drug Resist Update 7: 41-51.

SEPP T, JARVEKULG L AND SAARMA M. 1992. Investigations of virus-protozoa relationships in the model of freeliving ciliate Tetrahymena pyriformis and adenovirus type 3 . Eur J Protistol 28: 170-174.

SHENK T. 1996. Adenoviridae: The viruses and their replication. In: Fields BN, Knipe DM, Howley PM, Chanock RM, Melnick JL, Monath TP, Roizman B, Straus SE (Eds), Virology. Vol 2, Lippincott-Raven, $3^{\text {rd }}$ ed., Philadelphia, USA, p. 2111-2148.

SUHRE K. 2005. Gene and genome duplication in Acanthamoeba polyphaga Mimivirus. J Virol 79: 14095-14101.

THOMAS V AND GREUB G. 2010. Amoeba/Amoebal Symbiont Genetic Transfers: Lessons from Giant Virus Neighbours. Intervirol 53: 254-267.

TSVETKOVA N, Schild M, PANAIOTOV S, KURDOVAMINTCHEVA R, GOTTSTEIN B, WALOCHNIK J, ASPÖCK H, LUCAS MS AND MÜLLER N. 2004. The identification of free-living environmental isolates of amoebae from Bulgaria. Parasitol Res 92: 405-413.

VAN HEERden J, EHLERS MM, HeIM A AND GRABOW WOK. 2005. Prevalence, quantification and typing of adenoviruses detected in river and treated drinking water in South Africa. J Appl Microbiol 99: 234-242.

VESALUOMA M, KALSO S, JOKIPII L, WARHURST D, PÖNKÄ A AND TERVO T. 1995. Microbiological quality in Finnish public swimming pools and whirlpools with special reference to free living amoebae: a risk factor for contact lens wearers? Br J Ophthalmol 79: 178-181.

Wolf S, HeWITT J AND GREENING GE. 2010. Viral multiplex quantitative PCR assays for tracking sources of fecal contamination. Appl Environ Microbiol 76: 1388-1394.

WYN-JONES AP ET AL. 2011. Surveillance of adenoviruses and noroviruses in European recreational waters. Water Res 45: 1025-1038.

YUTIN N AND KOONIN EV. 2009. Evolution of DNA ligases of nucleo-cytoplasmatic large DNA viruses of eukaryotes: a case of hidden complexity. Biol Direct 4: 51. 